\title{
ASSESSMENT OF ECOLOGICAL INTEGRAL INDEX OF RURAL SETTLEMENTS DEVELOPMENT IN THE RADIOACTIVELY CONTAMINATED TERRITORY BASED ON DRINKING WATER QUALITY INDICATORS
}

\author{
Valerko R. A., Herasymchuk L. O.
}

\section{INTRODUCTION}

Rural residential area is a complex and multifunctional system which is currently in crisis. Environmental problems of rural settlements are caused by the fact that agriculture has been intensive for a long time, which results in pollution of soil, food and drinking water by various chemical pollutants. In addition, the Chornobyl accident has made a significant contribution to the environmental situation in Ukrainian villages. The demographic situation is also catastrophic. According to the General Directorate of Statistics, in rural areas, the number of population and birth rate are decreasing compared to cities, while the mortality rate is rising.

Water is an integral part of a safe and healthy life. It is known that the health status of the population and its morbidity depend on water quality. Mostly, rural settlements do not have centralized water supply, and therefore their population consumes water from sources of non-centralized water supply: wells, bores, underground sources, etc. Monitoring study of such sources indicates that the drinking water is not in compliance with organoleptic, sanitary, chemical and bacteriological quality indicators. Above-limit values of such indicators as nitrates, nitrites, total iron, sulphates, chlorides, etc. are particularly common.

Currently, private farms are located in rural settlements or are adjacent to them; they often do not meet the requirements for the application of fertilizers and plant protection products, which leads to contamination of soil, vegetables and groundwater by toxic substances, in particular nitrates ${ }^{1}$. Furthermore, the owners and users of private plots do not know or neglect the rules of farm management, including the maintenance and location of wells and bores ${ }^{2}$.

${ }^{1}$ Ecological assessment of vegetable products grown in the city of Zhytomyr and its residential suburb / R. Valerko et al. Ukrainian Journal of Ecology. 2018. № 8 (1). P. 927-938. DOI: 10.15421/2018_295.

2 Палапа Н., Тамір Б. Особливості формування екологічного стану на сільських селітебних територіях зони посиленого радіоекологічного контролю. Таврійський науковий вісник. № 91. С. 175-180. 
Therefore, monitoring study of drinking water quality from the sources of non-centralized water supply in rural settlements is necessary to ensure the decent and safe life of the population.

A large number of domestic and foreign researchers are engaged in the environmental assessment of drinking water from the sources of noncentralized water supply in rural settlements $\mathrm{s}^{3 ; 4 ; 5 ; 6 ; 7 ; 8}$. Some of them studied this problem in the Zhytomyr region ${ }^{9 ; 10}$. Most studies carried out in the radioactively contaminated area in the region are mainly concentrated on the assessment of the quality of life ${ }^{11}$ and health of the population ${ }^{12}$, including the oncological and epidemiological situation ${ }^{13}$. However, there are not enough studies that highlight the issue of environmental assessment of

3 Кравченко М. Фізико-хімічний аналіз природної питної води різних джерел водопостачання. Екологічна безпека та природокористування. 2015. № 3 (19). С. 52-60.

${ }^{4}$ Гловин Н., Павлів О. Дослідження якості водних ресурсів децентралізованого водопостачання сільських місцевостей у межах Бережанського району. Науковий вісник Львівського національного університету ветиеринарної медицини та біотехнологій імені С.3. Гжицького. 2018. Т. 20. № 84. C. 109-113. DOI: 10.15421 /nvlvet8420.

${ }^{5}$ Schullehner Jörg, Hansen Birgitte. Nitrate exposure from drinking water in Denmark over the last 35 years. Environmental Research Letters. 2014. № 9. 095001. DOI: 10.1088/1748-9326/9/9/095001.

${ }^{6}$ Njeze G., Dilibe U., Ilo C. Nitrate and drinking water from private wells: Will there be an epidemic of cancers of the digestive tract, urinary bladder and thyroid? Nigerian Journal of Clinical Practice. 2014. № 2. P. 178-182. DOI: 10.4103/1119-3077.127543.

7 Perceptions of drinking water quality from private wells in Alberta: A qualitative study / Abraham Munene et al. Canadian Water Resources Journal. 2019. Vol. 44. 3. P. 291-306. DOI: 10.1080/07011784.2019.1601599.

${ }^{8}$ Total coli form and Escherichia coli contamination in rural well water: analysis for passive surveillance / Jesse Invik et al. Journal of Water and Health. 2017. № 15 (5). P. 729-740. DOI: 10.2166/wh.2017.185.

Валерко Р., Герасимчук Л. Обгрунтування заходів щодо підвищення якості питної води джерел нецентралізованого водопостачання сільських населених пунктів в умовах Житомирської області. Збірник наукових праць Подільського держсавного аграрно-технічного університету. 2014. Спец. вип. : Сучасні проблеми збалансованого природокористування. С. 209-212.

${ }^{10}$ Герасимчук Л. Роль нітратного забруднення овочевої продукції та питної води у формуванні неканцерогенного ризику для населення с. Лука Житомирського району. Вісник Житомирського національного агроекологічного університету. 2015. T. 1. № 2 (50). C. 55-63.

${ }^{11}$ Quality of life of the population resident at the radioactively contaminated area in Zhytomyr Region / L. Romanchuk et al. Ukrainian Journal of Ecology. 2019. № 9 (4). P. 476-483.

${ }_{12}$ The reproductive health of the female residents in the areas of Ukraine affected by the radioactive contamination (2007-2017) / Y. Antypkin et al. Problems of radiation medicine and radiobiology. 2019. Dec 24. P. 284-295. DOI: $10.33145 / 2304-8336-2019$ 24-284-295.

13 Demographic and onco-epidemiological situation in radioactive contaminated territory of Zhytomyr Oblast / L. Herasymchuk et al. Regulatory Mechanisms in Biosystems. 2019. № 10 (1). P. 32-38. DOI: 10.15421/021905. 
drinking water quality from the sources of non-centralized water supply in the radioactively contaminated territory of Zhytomyr region ${ }^{14}$.

Many studies were focused on assessing excess levels of water quality indicators ${ }^{15,16}$, on assessing carcinogenic and non-carcinogenic risks to human health when consuming water that does not meet the standards ${ }^{17 ; 18}$, and also common negative effects on human health were established ${ }^{19 ; 20 ; 21 ; 22 ; 23}$.

In our opinion, it is relevant to assess the ecological integral index of rural settlements development on the basis of quality indicators of drinking water such as the content of nitrates, total iron and the $\mathrm{pH}$-value, which determined the choice of this direction of the study.

The purpose of this study is to determine the quality indicators of drinking water from the sources of non-centralized water supply in rural settlements located in the radioactively contaminated territory of Zhytomyr region, and on this basis, to assess the ecological integral index of rural settlements development.

The investigation of the drinking water quality from the sources of noncentralized water supply in rural settlements was carried out in radioactively contaminated areas of Zhytomyr region during 2019. Drinking water samples were collected from wells and bores in the following settlements:

- Korosten raion: village Berestovets, village Bekhy, village Voroneve;

${ }^{14}$ Коткова Т., Федючка М., Піціль А. Екологічний моніторинг якості питної води водогонів і колодязів Лугинського району Житомирської області на вміст азоту амонійного та нітратів. Науковий вісник Начіонального лісотехнічного університету України. 2017. Т. 27. № 10. C. 81-85. DOI: 10.15421/40271014.

${ }^{15}$ Медико-екологічна проблема сумарного надходження нітратів в організм людини 3 питною водою та харчовими продуктами та шляхи ії вирішення / Ю. Бондаренко та ін. Актуальные вопросы транспортной медицины. 2011. № 1 (23). С. 82-86.

16 Чиж В. Водно-нітратна метгемоглобінемія: напрями вирішення проблеми. СЕС. Профілактична медицина. 2013. № 1. С. 54-56.

17 Абдулмуталимова Т., Ревич Б. Оценка канцерогенного риска здоровью населения, обусловленного высоким содержанием мышьяка в питьевой артезианской воде Северного Дагестана. Гигиена и санитария. 2017. № 96 (8). C. 743-746. DOI: 10.1882/0016-9900-2017-96-8-743-746.

${ }_{18}$ Nitrate in drinking water and colorectal cancer risk: A nation wide population based cohort study / Jörg Schullehner et al. International Journal of Cancer. 2018. Vol. 143. 1. P. 73-79. DOI: 10.1002/ijc.31306.

${ }^{19}$ Егорова Н., Канатникова Н. Влияние железа в питьевой воде на заболеваемость населения г. Орла. Гигиена и санитария. 2017. № 96 (11). С. 1049-1053. DOI: 10.1882/0016-9900-2017-96-11-1049-1053.

${ }^{20}$ Прокопов В., Липовецька О., Антомонов М. Вплив мінерального складу питної води на хвороби системи кровообігу. Довкілля та здоров'я. 2016. № 1. С. 54-58.

${ }^{21} \mathrm{Li}$ Peiyue,Wu Jianhua. Drinking Water Quality and Public Health. Exposure and Health. 2019. 11. P. 73-79. DOI: 10.1007/s12403-019-00299-8.

${ }_{22}$ A Review of Adverse Effects and Benefits of Nitrate and Nitrite in Drinking Water and Food on Human Health / M. Parvizishad et al. Health Scope. 2017. № 6 (3) : e14164. DOI: $10.5812 /$ jhealthscope. 14164 .

${ }^{23}$ Drinking Water Nitrate and Human Health: An Undated Review / M. Ward et al. International Journal of Environmental Research and Public Health. 2018. № 15 (7) : 1557. DOI: 10.3390/ijerph15071557. 
- Luhyny raion: small town Luhyny, village Stari Novaky, village Chervona Voloka;

- Narodychi raion: village Bazar, village Huto-Mariatyn, village Davydky, small town Narodychi, village Selets, village Khrystynivka;

- Olevskraion: village Bilokorovychi, village Zubkovychi.

Analytical study of drinking water for nitrate, total iron content and $\mathrm{pH}$ value was carried out according to conventional methods in the Measuring Laboratory of the Scientific and Educational Center for Ecology and Environmental Protection of Zhytomyr National Agroecological University.

The methodology described in the work of I. Pustovit ${ }^{24}$ was used to calculate the integral ecological index of rural settlements development on the basis of drinking water quality indicators.

\section{Brief description of radioactively contaminated areas of Zhytomyr region}

Zhytomyr region is one of the most radioactively contaminated regions. About 350,000 people live in the region with the status of victims of the Chornobyl accident. The areas of its northern part are especially contaminated. About 674 settlements, which belong to different zones of radioactive contamination, are located in radioactively contaminated territories $^{25}$ (Table 1).

Korosten raion is an administrative division in Zhytomyr region with the center town Korosten. The population is 27,190 (as of March 29, 2016). The area of the raion is $1,735 \mathrm{~km}^{2}$. It was created in 1923 . Korosten raion is located in the northern part of Zhytomyr region. In the west, it borders on Yemilchyno, Luhyny raions, in the south on Khoroshiv raion, in the north on Ovruch and Narodychi raions, in the east on Malyn raion. There are 108 settlements in the area. The main rivers are the Uzh and the Irsha (Dnieper (basin) $)^{26}$.

24 Пустовіт I. Методика визначення екологічно-соціальної оцінки територій сільських населених пунктів України. Наукові доповіді Національного університету біоресурсів $i$ природокористування Украӥни. 2013. № 1 (37). URL: http://www.nbuv.gov.ua/e-journals/Nd/2013_1/13pim.pdf.

Ковальова С., Ільніцька О., Рубан I. Сучасний радіологічний стан сільськогосподарських угідь Житомирського Полісся. Подільський вісник: сільське господарство, техніка, економіка. 2017. Вип. 26. Сільськогосподарські науки. C. $72-79$.

Житомирська обласна універсальна наукова бібліотека ім. Олега Ольжича. URL: http://www.lib.zt.ua. 
Table 1

List of settlements in the Zhytomyr region referred to radioactive contamination zones following the Chornobyl disaster

\begin{tabular}{|c|c|c|c|}
\hline Exclusion zone & $\begin{array}{c}\text { Zone of } \\
\text { unconditional } \\
\text { (obligatory) } \\
\text { resettlement }\end{array}$ & $\begin{array}{c}\text { Zone of } \\
\text { guaranteed } \\
\text { voluntary } \\
\text { resettlement }\end{array}$ & $\begin{array}{l}\text { Zone of enhanced } \\
\text { radioecological } \\
\text { control }\end{array}$ \\
\hline \multicolumn{4}{|c|}{ Narodychi raion } \\
\hline 4 & 36 & 36 & 8 \\
\hline \multicolumn{4}{|c|}{ Ovruch raion } \\
\hline 3 & 10 & 107 & 30 \\
\hline \multicolumn{4}{|c|}{ Korosten raion } \\
\hline- & 1 & 26 & 86 \\
\hline \multicolumn{4}{|c|}{ Luhyny raion } \\
\hline 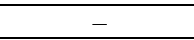 & 4 & 35 & 11 \\
\hline \multicolumn{4}{|c|}{ Malyn raion } \\
\hline- & 1 & - & 103 \\
\hline \multicolumn{4}{|c|}{ Emilchyn raion } \\
\hline- & - & 44 & 75 \\
\hline \multicolumn{4}{|c|}{ Olevsk raion } \\
\hline- & 2 & 45 & 14 \\
\hline
\end{tabular}

According to the Decree of the Cabinet of Ministers of the Ukrainian $\mathrm{SSR}^{27}, 113$ rural settlements in Korosten raion are included in the radioactively contaminated zones, one of them belongs to the zone of unconditional (obligatory) resettlement (village Obykhody) (Fig. 1).

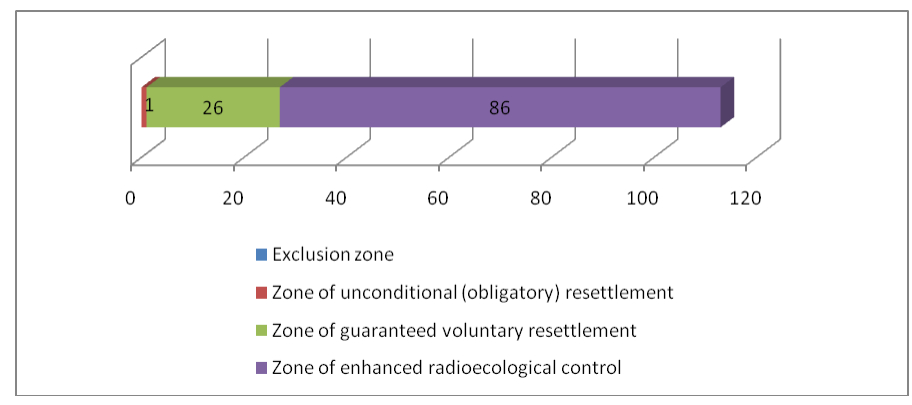

Fig. 1. Number of settlements in Korosten raion that are included in the radioactively contaminated zones, units

27 Про організацію виконання постанов Верховної Ради Української РСР про порядок введення в дію законів Української РСР «Про правовий режим території, що зазнала радіоактивного забруднення внаслідок чорнобильської катастрофи» та «Про статус i соціальний захист громадян, які постраждали внаслідок чорнобильської катастрофи» : постанова Кабінету Міністрів Української РСР від 23 липня 1991 p. № 106. URL: https://zakon.rada.gov.ua/laws/show/106. 
Luhyny raion is an administrative division in the northern part of Zhytomyr region located in the Polissia lowland with the center in small town Luhyny. The population is 16,561 (as of February 1, 2016). The area of the raion is $944 \mathrm{~km}^{2}$. It was created in 1923. In the north-west, it borders on Ovruch raion, in the south and south-east on Korosten raion, in the southwest on Yemilchyno raion and in the west and north-west on Olevsk raion.

50 rural settlements in Luhyny raion are included in the radioactively contaminated zones as a result of the Chornobyl accident; four of them belong to the zone of unconditional (obligatory) resettlement (Fig. 2).

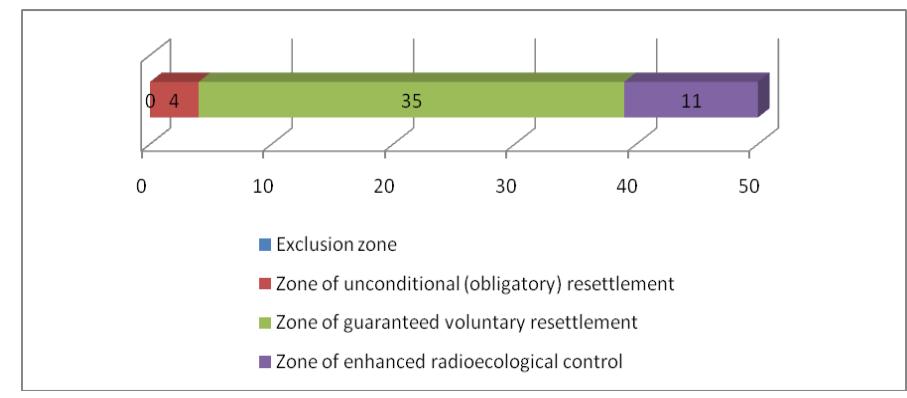

Fig. 2. Number of settlements in Luhyny raion that are included in the radioactively contaminated zones, units

Narodychi raion is located in the northeast of the region within the Polissia lowland. One river with four tributaries flows through the raion. The western part of the raion is within the Zhytomyr Polissia, while the eastern part is within the Kyiv Polissia. In the north, the raion borders on the Narovliany raion of the Gomel region of the Republic of Belarus. The population is 9,393 people (as of February 1, 2016).

The environmental situation in the raion is determined by the serious consequences of the Chornobyl accident. All four radioactive contamination zones are here. In total, 84 settlements are included in such zones, of which 4 belong to the exclusion zone, namely village Dovhyi Lis, village Motyli, village Nove Sharne, village Omelnyky (Fig. 3). 


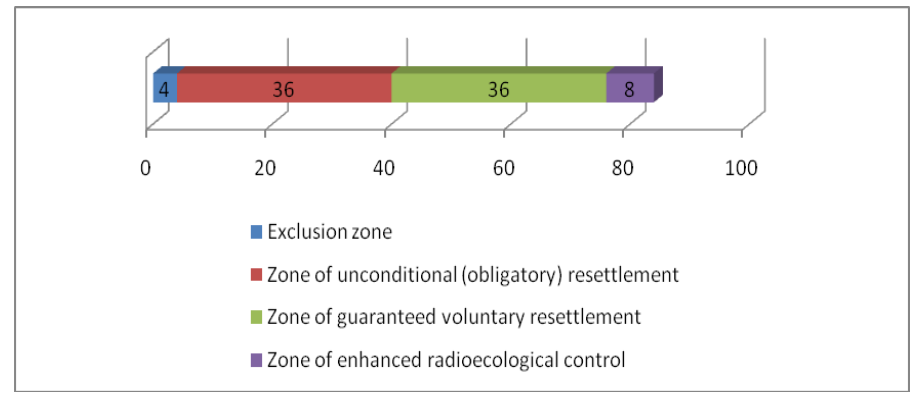

Fig. 3. Number of settlements in Narodychi raion that are included in the radioactively contaminated zones, units

Olevsk raion as an administrative division was created in 1923. The area of the raion is 224.7 thousand hectares or $7,1 \%$ of the territory of the region.

The length of the raion from west to east is about $50 \mathrm{~km}$, from north to south $80 \mathrm{~km}$. The whole territory of the Olevskraion is located within the Polissia lowland and only the northeastern part on the spurs of the Slovechansk-Ovruch Ridge. In the north, it borders on the Lelchytsya raion of the Republic of Belarus, in the west on the Rokytne raion of Rivne region, in the east and south on Luhyny, Yemilchyno, Novograd-Volynskyi raions of Zhytomyr region. 61 settlements of Olevsk raion are included in the radioactively contaminated zones (Fig. 4).

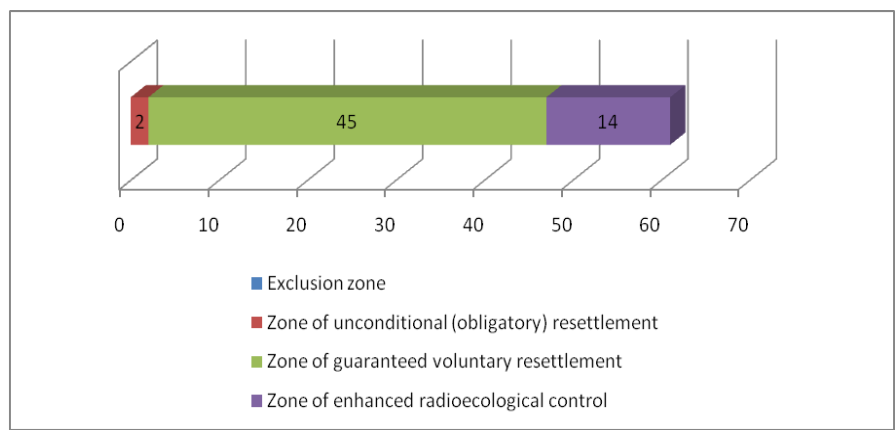

Fig. 4. Number of settlements in Olevsk raion that are included in the radioactively contaminated zones, units 


\section{Calculation of environmental integral index based on water quality indicators}

One of the main indicators of drinking water quality is the $\mathrm{pH}$-value, a hydrogen index that indicates the presence of hydrogen ions in water. In Ukraine, this indicator is normalized by DSanPIN (State Sanitary Regulations and Standards) 2.2.4-171-10 "Hygienic Requirements for the Quality of Water Intended for Human Consumption", which defines its safety standards that range from 6,5 to 8,5. The investigation of drinking water samples from sources of non-centralized water supply in rural settlements of the Korosten raion showed that on average, the $\mathrm{pH}$-value and the total iron indicators meet the standards (Table 2).

Table 2

Total iron content and $\mathrm{pH}$-value in drinking water from the sources of non-centralized water supply in rural settlements of Korosten raion

\begin{tabular}{|c|c|c|c|c|}
\hline \multirow[b]{2}{*}{ Settlement } & \multicolumn{2}{|c|}{ pH-value } & \multicolumn{2}{|c|}{ Total iron content, $\mathrm{mg} / \mathrm{dm}^{3}$} \\
\hline & $\begin{array}{l}\text { Mean } \\
\text { value }\end{array}$ & $\begin{array}{c}\text { \% of samples } \\
\text { that do not } \\
\text { meet the } \\
\text { standards }\end{array}$ & $\begin{array}{c}\text { Mean value, } \\
\text { mg/dm }\end{array}$ & $\begin{array}{l}\% \text { of samples that } \\
\text { do not meet the } \\
\text { standards }\end{array}$ \\
\hline village Berestovets & 6,86 & 0 & 0,1580 & 0 \\
\hline village Bekhy & 6,75 & 0 & 0,2966 & 0 \\
\hline village Voroneve & 6,59 & 30 & 0,1252 & 0 \\
\hline
\end{tabular}

Nitrates are salts of nitric acid. Their content in drinking water from the sources of non-centralized water supply depends primarily on the state of the source. All the wells under investigation were built more than 30 years ago, and therefore many of them do not meet the technical requirements, thus land runoff (rain and melt water) seeps into the well. Household sewage on the farmland is most often contaminated with livestock waste, which increases the level of nitrogen compounds in water. In addition, the increased nitrate content in drinking water can also be caused by the use of organic, mineral fertilizers and plant protection agents, as well as failure to adhere to the rules for the location of toilets and places for keeping livestock.

Excess nitrate concentration was detected in all settlements of Korosten raion. The worst situation is recorded for the village Bekhy, where the average content of nitrates exceeds the allowable by almost 2 times (Fig. 5).

Consumption of such water can be hazardous to human health, since increased nitrate levels can cause poisoning, as well as diseases such as methemoglobinemia, which is the inability of hemoglobin to carry oxygen through the blood. Nitrate compounds are particularly dangerous for young children and infants. 


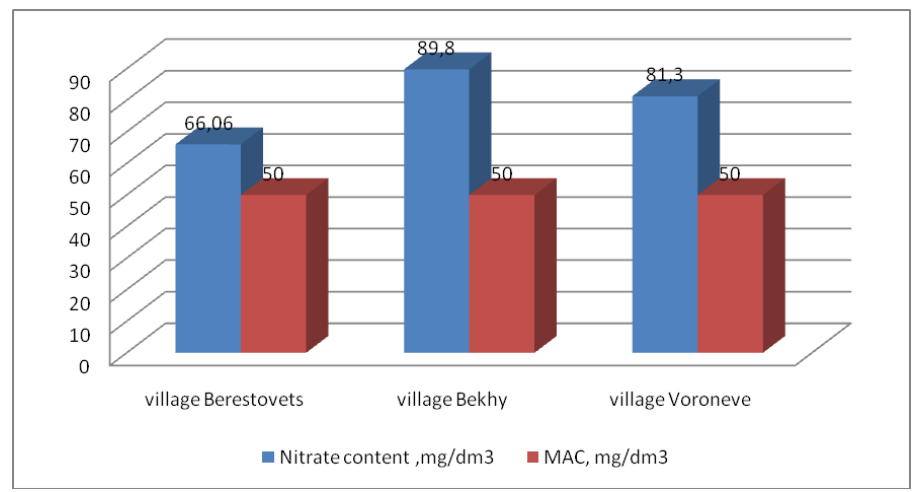

Fig. 5. Average nitrate content in drinking water from the sources of noncentralized water supply in rural settlements of Korosten raion, $\mathbf{m g} / \mathrm{dm}^{3}$

It was found out that in the samples of drinking water taken in the village Chervona Voloka of Luhyny raion, the average content of hydrogen index is 6,24 . The $\mathrm{pH}$-value is lower than 6,5, which indicates an increase in the acidity of such water, which significantly deteriorates its quality and makes it dangerous for human health (Table 3). The total iron content varied within normal limits.

Table 3

Total iron content and $\mathrm{pH}$-value in drinking water from the sources of non-centralized water supply in rural settlements of Luhyny raion

\begin{tabular}{|c|c|c|c|c|}
\hline \multirow{2}{*}{ Settlement } & \multicolumn{2}{|c|}{$\mathbf{p H}$-value } & \multicolumn{2}{c|}{ Total iron content, mg/dm } \\
\cline { 2 - 5 } & $\begin{array}{c}\text { Mean } \\
\text { value }\end{array}$ & $\begin{array}{c}\text { \% of samples } \\
\text { that do not meet } \\
\text { the standards }\end{array}$ & $\begin{array}{c}\text { Mean value, } \\
\mathbf{m g} / \mathbf{d m}^{\mathbf{3}}\end{array}$ & $\begin{array}{c}\text { \% of samples } \\
\text { that do not meet } \\
\text { the standards }\end{array}$ \\
\hline small town Luhyny & 6,85 & 0 & 0,2547 & 0 \\
\hline village Stari Novaky & 6,78 & 0 & 0,1578 & 0 \\
\hline $\begin{array}{c}\text { village Chervona } \\
\text { Voloka }\end{array}$ & 6,24 & 50 & 0,178 & 0 \\
\hline
\end{tabular}

It was recorded that the average nitrate content was higher in almost all investigated settlements of Luhyny raion; it exceeded the norm by 1,4-3 times. The worst situation was observed in small town Luhyny, where the average nitrate content is $150 \mathrm{mg} / \mathrm{dm}^{3}$, which exceeds the norm by 3 times (Fig. 6). 


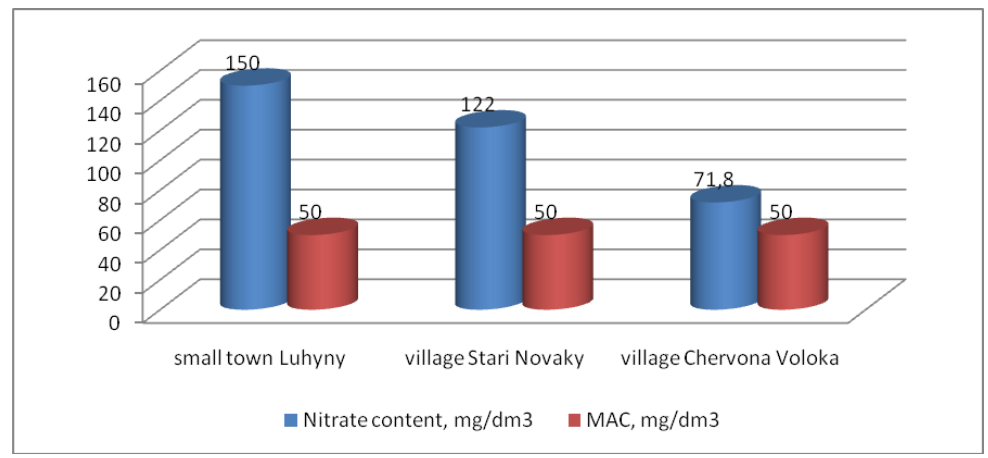

Fig. 6. Average nitrate content in drinking water from the sources of noncentralized water supply in rural settlements of Luhyny raion, $\mathrm{mg} / \mathrm{dm}^{3}$

Investigation of drinking water for the $\mathrm{pH}$-value showed that the decrease in the hydrogen index to 6,27 was recorded in the village Bezar of Narodychi raion. However, on average, its values do not exceed the normative ones.

According to the standard, the content of total iron in drinking water from the sources of non-centralized water supply should not exceed $1,0 \mathrm{mg} / \mathrm{dm}^{3}$. In $25 \%$ of the water samples taken in the small town Narodychi and in $50 \%$ of the samples from the village Selets this indicator exceeded the norm (Table 4).

Despite the fact that iron is an important microelement involved in the process of hematopoiesis, there are side effects of the continued use of its increased amounts. The first consequences of regular use of water with high iron content are disorders of the gastrointestinal tract: flatulence, bloating, nausea. Also, allergic reactions and, rarely, hemochromatosis can develop, resulting in systemic damage to the liver, cardiovascular and endocrine systems.

In addition, the use of water with high amount of iron negatively affects the state of home appliances, clothing, and may deteriorate the taste of food.

Table 4

Total iron content and pH-value in drinking water from the sources of non-centralized water supply in rural settlements of Narodychi raion

\begin{tabular}{|c|c|c|c|c|}
\hline \multirow{2}{*}{ Settlement } & \multicolumn{2}{|c|}{ pH-value } & \multicolumn{2}{|c|}{ Total iron content, mg/dm } \\
\cline { 2 - 5 } & $\begin{array}{c}\text { Mean } \\
\text { value }\end{array}$ & $\begin{array}{c}\text { \% of samples that } \\
\text { do not meet the } \\
\text { standards }\end{array}$ & $\begin{array}{c}\text { Mean value, } \\
\text { mg/dm }\end{array}$ & $\begin{array}{c}\text { \% of samples } \\
\text { that do not meet } \\
\text { the standards }\end{array}$ \\
\hline village Bazar & 7,3 & 20 & 0,1976 & 0 \\
\hline $\begin{array}{c}\text { village Huto- } \\
\text { Mariatyn }\end{array}$ & 7,28 & 0 & 0,2154 & 0 \\
\hline village Davydky & 6,95 & 0 & 0,1258 & 0 \\
\hline $\begin{array}{c}\text { small town } \\
\text { Narodychi }\end{array}$ & 6,85 & 0 & 0,39035 & 25 \\
\hline village Selets & 7,08 & 0 & 0,5635 & 50 \\
\hline village Khrystynivka & 6,89 & 0 & 0,1382 & 0 \\
\hline
\end{tabular}


All settlements of Narodychi raion were characterized by excess nitrate content, except village Selets, where its average content is $32,5 \mathrm{mg} / \mathrm{dm}^{3}$ (Fig. 7).

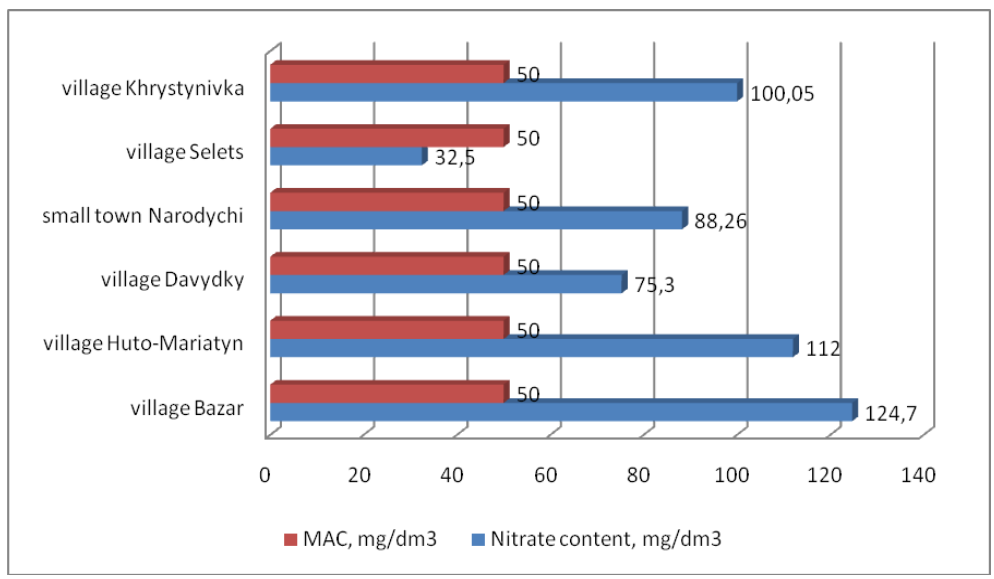

Fig. 7. Average nitrate content in drinking water from the sources of noncentralized water supply in rural settlements of Narodychi raion, $\mathrm{mg} / \mathrm{dm}^{3}$

As a result of analytical study of drinking water from wells and bores in rural residential areas of Olevsk raion, it was found out that in none of the cases the total iron content and the $\mathrm{pH}$-value exceeded the norm (Table 5). Unfortunately, this cannot be stated about the nitrate content, which exceeds the average in settlements by 1,34-1,72 times (Fig. 8).

Table 5

Total iron content and $\mathrm{pH}$-valuein drinking water from the sources of non-centralized water supply in rural settlements of Olevsk raion

\begin{tabular}{|c|c|c|c|c|}
\hline \multirow{2}{*}{ Settlement } & \multicolumn{2}{|c|}{ pH-value } & \multicolumn{2}{|c|}{ Total iron content, $\mathbf{~ m g / \mathbf { d m } ^ { 3 }}$} \\
\cline { 2 - 5 } & $\begin{array}{c}\text { Mean } \\
\text { value }\end{array}$ & $\begin{array}{c}\text { \% of samples } \\
\text { that do not } \\
\text { meet the } \\
\text { standards }\end{array}$ & $\begin{array}{c}\text { Mean value, } \\
\mathbf{m g} / \mathbf{d m}^{3}\end{array}$ & $\begin{array}{c}\text { \% of samples } \\
\text { that do not meet } \\
\text { the standards }\end{array}$ \\
\hline village Bilokorovychi & 6,72 & 0 & 0,4658 & 0 \\
\hline village Zubkovychi & 6,42 & 0 & 0,0141 & 0 \\
\hline
\end{tabular}




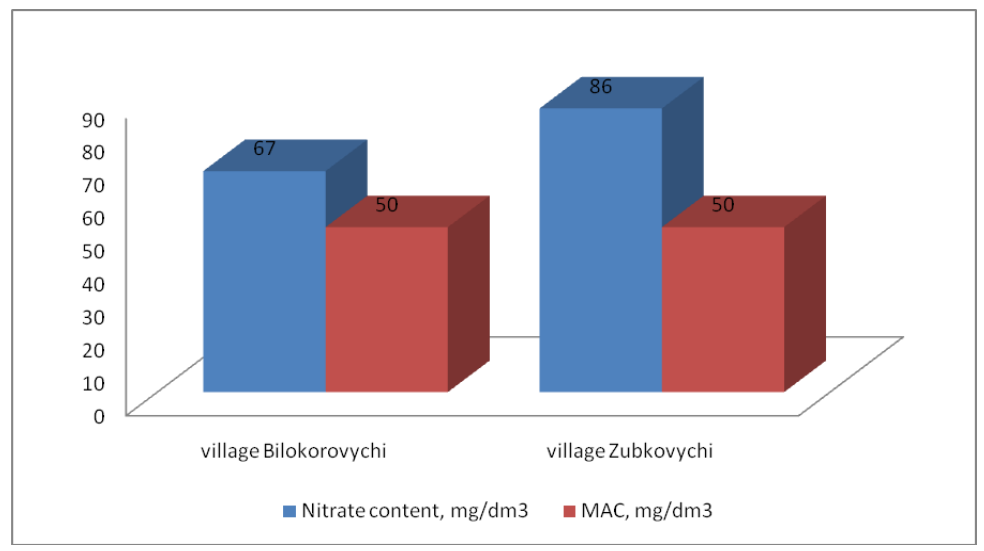

Fig. 8. Average nitrate content in drinking water from the sources of noncentralized water supply in rural settlements of Olevsk raion, $\mathrm{mg} / \mathrm{dm}^{3}$

The investigation of drinking water from sources of non-centralized water supply in rural residential areas of radioactively contaminated territories of Zhytomyr region make it possible to state that the highest contribution to the risk to the health of the rural population is the increased content of nitrates, the excess of which is recorded in almost all points.

In order to reduce the risk of contamination of drinking water from wells with nitrates, it is necessary to observe the requirements for their content, namely:

- keep the area around the well clean, prevent melt and rain water from entering the water;

- adhere to the minimum necessary sanitary breaks between the household buildings and the well;

- carry out a laboratory water analysis twice a year;

- clean the well once a year;

- if possible, use disinfectants for water purification.

In order to assess the environmental integral index of rural settlements development by the quality indicators of drinking water, a 5 point scale was used: 1 - very bad, 2 - unsatisfactory, 3 - satisfactory, 4 - good, 5 - excellent. The normative values which were used to assess the index are given in Table 6.

It was found out that the majority of rural settlements (9 settlements) are in a satisfactory condition according to the integral index of drinking water quality, while 5 village settlements are in a good condition (Table 7). 
Reference table for determining the integral index based on quality indicators of drinking water from the sources of non-centralized water supply

\begin{tabular}{|c|c|c|c|c|c|}
\hline Indicator & \multicolumn{5}{|c|}{ Specified value } \\
\hline $\begin{array}{c}\text { Nitrate } \\
\text { content, } \\
\mathrm{mg} / \mathrm{dm}^{3}\end{array}$ & $>50,0$ & $10,0-50,0$ & $7,1-10,0$ & $5,0-7,0$ & $<5,0$ \\
\hline $\mathrm{pH}$ & $>8,5$ & $6,0-8,5$ & $6,0-8,0$ & $6,5-8,5$ & $6,5-7,0$ \\
\hline $\begin{array}{c}\text { Total iron } \\
\text { content, } \\
\text { mg/dm }\end{array}$ & $>2.0$ & $1,0-2,0$ & $0,3-1,0$ & $0,2-0,3$ & $<0,2$ \\
\hline Points & 1 & 2 & 3 & 4 & 5 \\
\cline { 2 - 6 } & very bad & unsatisfactory & satisfactory & good & excellent \\
\hline
\end{tabular}

Table 7

Integral index of rural settlements by the quality indicators of drinking water from the sources of non-centralized water supply

\begin{tabular}{|c|c|c|c|c|c|c|c|}
\hline Settlement & $\begin{array}{l}\text { pH- } \\
\text { value }\end{array}$ & Points & $\begin{array}{l}\text { Total iron } \\
\text { content, } \\
\text { mg/dm }\end{array}$ & $\begin{array}{c}\text { Point } \\
\text { s }\end{array}$ & $\begin{array}{l}\text { Nitrate } \\
\text { content } \\
\underset{3}{\text { mg/dm }}\end{array}$ & $\begin{array}{l}\text { Point } \\
\text { s }\end{array}$ & $\begin{array}{l}\text { Integral } \\
\text { index }\end{array}$ \\
\hline \multicolumn{8}{|c|}{ Korosten raion } \\
\hline $\begin{array}{c}\text { village } \\
\text { Berestovets }\end{array}$ & 6,86 & 5 & 0,1580 & 5 & 66,06 & 1 & $3,7(4)$ \\
\hline village Bekhy & 6,75 & 5 & 0,2966 & 4 & 89,8 & 1 & $3,3(3)$ \\
\hline $\begin{array}{c}\text { village } \\
\text { Voroneve }\end{array}$ & 6,59 & 5 & 0,1252 & 5 & 81,3 & 1 & $3,7(4)$ \\
\hline \multicolumn{8}{|c|}{ Luhyny raion } \\
\hline $\begin{array}{c}\text { small town } \\
\text { Luhyny }\end{array}$ & 6,85 & 5 & 0,2547 & 4 & 150 & 1 & $3,3(3)$ \\
\hline $\begin{array}{c}\text { village } \\
\text { StariNovaky }\end{array}$ & 6,78 & 5 & 0,1578 & 5 & 122 & 1 & $3,7(4)$ \\
\hline $\begin{array}{c}\text { village } \\
\text { ChervonaVolok } \\
\mathrm{a} \\
\end{array}$ & 6,24 & 3 & 0,178 & 5 & 71,8 & 1 & 2,97 (3) \\
\hline \multicolumn{8}{|c|}{ Narodychi raion } \\
\hline village Bazar & 7,3 & 4 & 0,1976 & 5 & 124,7 & 1 & $3,3(3)$ \\
\hline $\begin{array}{c}\text { village Huto- } \\
\text { Mariatyn }\end{array}$ & 7,28 & 4 & 0,2154 & 4 & 112 & 1 & 2,97 (3) \\
\hline village Davydky & 6,95 & 5 & 0,1258 & 5 & 75,3 & 1 & $3,7(4)$ \\
\hline $\begin{array}{l}\text { small town } \\
\text { Narodychi }\end{array}$ & 6,85 & 5 & 0,39035 & 3 & 88,26 & 1 & $2,97(3)$ \\
\hline village Selets & 7,08 & 4 & 0,5635 & 3 & 32,5 & 2 & $2,97(3)$ \\
\hline $\begin{array}{c}\text { village } \\
\text { Khrystynivka }\end{array}$ & 6,89 & 5 & 0,1382 & 5 & 100,05 & 1 & $3,7(4)$ \\
\hline \multicolumn{8}{|c|}{ Olevsk raion } \\
\hline $\begin{array}{c}\text { village } \\
\text { Bilokorovychi }\end{array}$ & 6,72 & 5 & 0,4658 & 3 & 67 & 1 & 2,97 (3) \\
\hline $\begin{array}{c}\text { village } \\
\text { Zubkovychi }\end{array}$ & 6,42 & 3 & 0,0141 & 5 & 86 & 1 & 2,97 (3) \\
\hline
\end{tabular}




\section{CONCLUSIONS}

Thus, using the results of our own study, we calculated the ecological integral index of rural settlements development based on the quality indicators of drinking water from private wells and bores located in rural settlements of radioactively contaminated areas of Zhytomyr region.

The results of analytical study of drinking water from private wells regarding the $\mathrm{pH}$-value in rural settlements of Korosten, Luhyny, Narodychi and Olevsk raions indicate that almost in all settlements the hydrogen index was within normal limits. The only exceptions were village Chervona Voloka of Luhyny raion and village Zubkovychi of Olevsk raion, where the $\mathrm{pH}$-value of drinking water was reduced to 6,24 and 6,42 , respectively.

On average, the excessive total iron content was not observed in the drinking water in any of the investigated rural settlements.

The average content of nitrates in drinking water from the sources of non-centralized water supply in all rural settlements exceeded the norm by 1,34-3 times. Their highest content was recorded in small town Luhyny at the level of $150 \mathrm{mg} / \mathrm{dm}^{3}$.

The lowest nitrate content in the drinking water from private wells was recorded in the village Selets of Narodychi raion, where its average amount is $32,5 \mathrm{mg} / \mathrm{dm}^{3}$.

The calculation of the ecological integral index of rural settlements development based on the quality indicators of drinking water from the sources of non-centralized water supply showed that 9 studied settlements have a satisfactory level of development, and 5 of them good level of development.

Further studies should also take into account the social and rural development indexes of rural settlements development.

\section{SUMMARY}

To assess the value of the ecological integral index of rural settlements development of radioactively contaminated areas in Zhytomyr region on the basis of quality indicators of drinking water from the sources of noncentralized water supply. The investigation was carried out in the rural settlements of Korosten (3 settlements), Luhyny (3 settlements), Narodychi (6 settlements) and Olevsk raions (2 settlements) in Zhytomyr region, as they are included in the radioactively contaminated territories. In total, 14 rural settlements were investigated. The assessment of drinking water quality from the sources of non-centralized water supply was based on the following indicators: $\mathrm{pH}$-value, nitrate content and total iron content. On its basis, the ecological integral index was calculated. Currently, population in rural settlements uses water from wells and bores because almost all rural areas of Ukraine do not have centralized water supply. The reasons for the deterioration of drinking water quality from the sources of non-centralized water supply in rural settlements are as follows: the formation of a large number of private agricultural enterprises that are engaged in intensive 
farming, and the capacity of which is located in or near the rural settlements, and also the fact that the rules of farm management are neglected by the owners of private farms. Particularly dangerous is the situation regarding the content of nitrates in drinking water which comes to wells with melt water and groundwater. It was found out that in all samples of drinking water of the settlements under investigation (except village Selets of Narodychi raion) there is an excess of the normative nitrate content. On average, the total iron content in all settlements did not exceed the permissible level. Drinking water acidification was recorded in village Chervona Voloka of Luhyny raion, where the $\mathrm{pH}$-value was on average 6,24. The calculation of the ecological integral index of rural settlements development on the basis of the quality indicators of drinking water showed that in 9 of the studied settlements the development index is satisfactory, while in 5 settlements it is good. Thus, it was stated that drinking water from private wells in most rural settlements of radioactively contaminated areas of Zhytomyr region is contaminated with nitrates, which makes it unfit for consumption by the population. The ecological integral index of rural development based on the quality indicators of drinking water was determined as satisfactory.

\section{REFERENCES}

1. Ecological assessment of vegetable products grown in the city of Zhytomyr and its residential suburb / R. Valerko et al. Ukrainian Journal of Ecology. 2018. № 8 (1). P. 927-938. DOI: 10.15421/2018_295.

2. Палапа Н., Тамір Б. Особливості формування екологічного стану на сільських селітебних територіях зони посиленого радіоекологічного контролю. Таврійський науковий вісник. № 91. С. 175-180.

3. Кравченко М. Фізико-хімічний аналіз природної питної води різних джерел водопостачання. Екологічна безпека $\mathrm{ma}$ природокористування. 2015. № 3 (19). С. 52-60.

4. Гловин Н., Павлів О. Дослідження якості водних ресурсів децентралізованого водопостачання сільських місцевостей у межах Бережанського району. Науковий вісник Львівського національного університету ветиеринарної медищини та біотехнологій імені С.З. Гжицького. 2018. Т. 20. № 84. C. 109-113. DOI: 10.15421/nvlvet8420.

5. Schullehner Jörg, Hansen Birgitte. Nitrate exposure from drinking water in Denmark over the last 35 years. Environmental Research Letters. 2014. № 9. 095001. DOI: 10.1088/1748-9326/9/9/095001.

6. Njeze G., Dilibe U., Ilo C. Nitrate and drinking water from private wells: Will there be an epidemic of cancers of the digestive tract, urinary bladder and thyroid? Nigerian Journal of Clinical Practice. 2014. № 2. P. 178-182. DOI: 10.4103/1119-3077.127543.

7. Perceptions of drinking water quality from private wells in Alberta: A qualitative study / Abraham Munene et al. Canadian Water Resources Journal. 2019. Vol. 44. № 3. P. 291-306. DOI: 10.1080/07011784.2019.1601599. 
8. Total coli form and Escherichia coli contamination in rural well water: analysis for passive surveillance / Jesse Invik et al. Journal of Water and Health. 2017. 15 (5). P. 729-740. DOI: 10.2166/wh.2017.185.

9. Валерко Р., Герасимчук Л. Обгрунтування заходів щодо підвищення якості питної води джерел нецентралізованого водопостачання сільських населених пунктів в умовах Житомирської області. Збірник наукових пращь Подільського державного аграрнотехнічного університету. 2014. Спец. вип. : Сучасні проблеми збалансованого природокористування. С. 209-212.

10. Герасимчук Л. Роль нітратного забруднення овочевої продукції та питної води у формуванні неканцерогенного ризику для населення с. Лука Житомирського району. Вісник Житомирського наиіонального агроекологічного університету. 2015. Т. 1. № 2 (50). С. 55-63.

11. Quality of life of the population resident at the radioactively contaminated area in Zhytomyr Region / L. Romanchuk et al. Ukrainian Journal of Ecology. 2019. № 9 (4). P. 476-483.

12. The reproductive health of the female residents in the areas of Ukraine affected by the radioactive contamination (2007-2017) / Y. Antypkin et al. Problems of radiation medicine and radiobiology. 2019. Dec 24. P. 284-295. DOI: 10.33145/2304-8336-2019-24-284-295.

13. Demographic and onco-epidemiological situationin radioactive contaminated territory of Zhytomyr Oblast / L. Herasymchuk et al. Regulatory Mechanisms in Biosystems. 2019. № 10 (1). P. 32-38. DOI: 10.15421/021905.

14. Коткова Т., Федючка М., Піціль А. Екологічний моніторинг якості питної води водогонів i колодязів Лугинського району Житомирської області на вміст азоту амонійного та нітратів. Науковий вісник Національного лісотехнічного університету Украӥни. 2017. T. 27. № 10. C. 81-85. DOI: 10.15421/40271014.

15. Медико-екологічна проблема сумарного надходження нітратів в організм людини з питною водою та харчовими продуктами та шляхи іiі вирішення / Ю. Бондаренко та ін. Актуальные вопросы транспортной медицины. 2011. № 1 (23). С. 82-86.

16. Чиж В. Водно-нітратна метгемоглобінемія: напрями вирішення проблеми. СЕС. Профілактична медицина. 2013. № 1. С. 54-56.

17. Абдулмуталимова Т., Ревич Б. Оценка канцерогенного риска здоровью населения, обусловленного высоким содержанием мышьяка в питьевой артезианской воде СеверногоДагестана. Гигиена и санитария. 2017. № 96 (8). C. 743-746. DOI: 10.1882/0016-9900-2017-96-8-743-746.

18. Nitrate in drinking water and colorectal cancer risk: A nation wide population - based cohort study / Jörg Schullehner et al. International Journal of Cancer. 2018. Vol. 143. 1. P. 73-79. DOI: 10.1002/ijc.31306.

19. Егорова Н., Канатникова Н. Влияние железа в питьевой воде на заболеваемость населения г. Орла. Гигиена и санитария. 2017. № 96 (11). C. 1049-1053. DOI: 10.1882/0016-9900-2017-96-11-1049-1053. 
20. Прокопов В., Липовецька О., Антомонов М. Вплив мінерального складу питної води на хвороби системи кровообігу. Довкілля та здоров'я. 2016. № 1. С. 54-58.

21. Li Peiyue, Wu Jianhua. Drinking Water Quality and Public Health. Exposure and Health. 2019. № 11. P. 73-79. DOI: 10.1007/s12403-01900299-8.

22. A Review of Adverse Effects and Benefits of Nitrate and Nitrite in Drinking Water and Food on Human Health / M. Parvizishad et al. Health Scope. 2017. № 6 (3) : e14164. DOI: 10.5812/jhealthscope.14164.

23. Drinking Water Nitrate and Human Health: An Updated Review / M. Ward et al. International Journal of Environmental Research and Public Health. 2018. № 15 (7) : 1557. DOI: 10.3390/ijerph15071557.

24. Пустовіт I. Методика визначення екологічно-соціальної оцінки територій сільських населених пунктів України. Наукові доповіді Національного університету біоресурсів $i$ природокористування Украӥни. 2013. № 1 (37). URL: http://www.nbuv.gov.ua/e-journals/ Nd/2013_1/13pim.pdf.

25. Ковальова С., Ільніцька О., Рубан І. Сучасний радіологічний стан сільськогосподарських угідь Житомирського Полісся. Подільський вісник: сільське господарство, техніка, економіка. 2017. Вип. 26. Сільськогосподарські науки. С. 72-79.

26. Житомирська обласна універсальна наукова бібліотека ім. Олега Ольжича. URL: http://www.lib.zt.ua.

27.Про організацію виконання постанов Верховної Ради Української РСР про порядок введення в дію законів Української РСР «Про правовий режим території, що зазнала радіоактивного забруднення внаслідок чорнобильської катастрофи» та «Про статус i соціальний захист громадян, які постраждали внаслідок чорнобильської катастрофи» : постанова Кабінету Міністрів Української РСР від 23 липня 1991 р. № 106. URL: https://zakon.rada.gov.ua/laws/show/106.

Information about authors: Valerko R. A., Candidate of Agricultural Sciences, Associate Professor at the Department of General Ecology Zhytomyr National Agroecological University 7, Staryi Blvd., Zhytomyr, 10008, Ukraine

Herasymchuk L. O.,

Candidate of Agricultural Sciences, Associate Professor at the Department of General Ecology Zhytomyr National Agroecological University 7, Staryi Blvd., Zhytomyr, 10008, Ukraine 